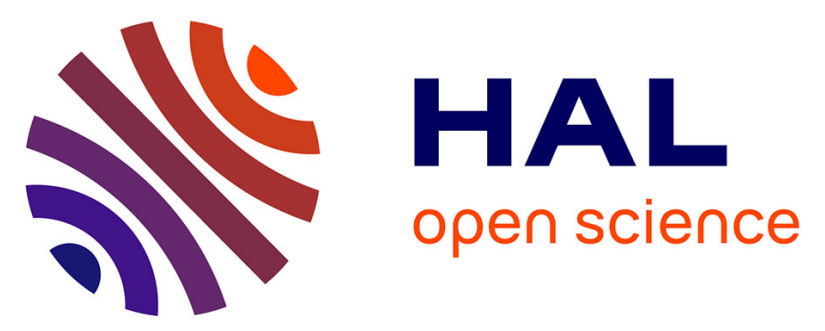

\title{
Mediterranean coastal conditions and litter type drive litter microbial responses to drought stress
}

\author{
Maya Kheir, Philip K Roche, Fabio Ziarelli, Anne Marie Farnet da Silva
}

\section{To cite this version:}

Maya Kheir, Philip K Roche, Fabio Ziarelli, Anne Marie Farnet da Silva. Mediterranean coastal conditions and litter type drive litter microbial responses to drought stress. European Journal of Soil Science, 2020, 71 (1), pp.106-118. 10.1111/ejss.12828 . hal-02138379

\section{HAL Id: hal-02138379 \\ https://hal.science/hal-02138379}

Submitted on 23 May 2019

HAL is a multi-disciplinary open access archive for the deposit and dissemination of scientific research documents, whether they are published or not. The documents may come from teaching and research institutions in France or abroad, or from public or private research centers.
L'archive ouverte pluridisciplinaire HAL, est destinée au dépôt et à la diffusion de documents scientifiques de niveau recherche, publiés ou non, émanant des établissements d'enseignement et de recherche français ou étrangers, des laboratoires publics ou privés. 


\title{
Mediterranean coastal conditions and litter type drive litter microbial responses to drought stress
}

\author{
Maya Kheir ${ }^{1,2}$ | Philip Roche $^{2}$ । Fabio Ziarelli ${ }^{3}$ | Anne Marie Farnet da Silva ${ }^{1}$
}

\author{
${ }^{1}$ Institut Méditerranéen de Biodiversité et \\ d'Ecologie Marine et Continentale, UMR \\ 7263, Aix Marseille Université, CNRS, \\ IRD, Avignon Université, Marseille, France \\ ${ }^{2}$ RECOVER-Risks, Ecosystems, \\ Vulnerability, Environment, Resilience, \\ IRSTEA, Aix en Provence, France \\ ${ }^{3}$ Aix Marseille Université, CNRS, \\ Spectropole Campus St Jérôme, Fédération \\ des Sciences Chimiques de Marseille, \\ Marseille, France

\section{Correspondence} \\ Anne Marie Farnet da Silva, Institut \\ Méditerranéen de Biodiversité et d'Ecologie \\ Marine et Continentale, UMR 7263, Aix \\ Marseille Université, CNRS, IRD, Avignon \\ Université, Campus l'Etoile, 13397 \\ Marseille cedex 20, France. \\ Email: anne-marie.farnet@imbe.fr

\section{Funding information} \\ BIODIVMEX from Program MISTRAL; \\ ECCOREV; French Government \\ Investissements d'Avenir Program of the \\ French National Research Agency, Grant/ \\ Award Number: $\mathrm{A} * \mathrm{MIDEX}$ project (ANR- \\ 11-IDEX-0001-02) ; Labex ot med , Grant/ \\ Award Number: ANR 11 LABX-0061; \\ Provence Alpes Côte d'Azur Region
}

\begin{abstract}
Warming and disturbance of precipitation dynamics are expected in the Mediterranean basin, resulting in longer, more intense drought and heat waves. Here we investigated how litter microbial functioning and responses to stress may be shaped by coastal environmental conditions, and whether this depends on litter type (Pinus halepensis, Pistacia lentiscus and their admixture). Mesocosms of monospecific and mixed litters collected from both inland and coastal areas were subjected to either control $\left(25^{\circ} \mathrm{C}, 60 \%\right.$ water holding capacity [WHC] $)$ or stress conditions (five drying-rewetting $\left[\mathrm{D} / \mathrm{rW}\right.$ ] cycles: 1 week of drying at $35^{\circ} \mathrm{C}, 1$ week at $25^{\circ} \mathrm{C}, 60 \%$ WHC). Litters were characterised using chemical analyses (C/N ratio and solidstate ${ }^{13} \mathrm{C}$ nuclear magnetic resonance [NMR] spectroscopy) and indicators of microbial activity (lignocellulolytic activities, basal respiration [BR], active microbial biomass $[\mathrm{MB}]$, fungal and bacterial catabolic profiles). Litter type controlled cellulases and basal respiration in litters from the inland area (e.g. positive correlations between these microbial indicators and di-O-alkyl $\mathrm{C}+\mathrm{O}$-alkyl $\mathrm{C}$ and $\% \mathrm{~N}$ ), whereas the litter-type effect was smoothed for the coastal area. Fungal and bacterial catabolic profiles were mainly shaped by the coastal conditions and litter type, respectively, indicating that fungi were more sensitive to coast-specific conditions and bacteria more sensitive to their immediate surrounding (i.e. litter type). After $\mathrm{D} / \mathrm{rW}$ cycles, microbial catabolic profiles showed: (a) a stronger stress impact on microbial communities from the inland area and (b) pre-exposure to coastal constraints limited the drought effect on decomposers from the coastal area. Our findings reveal that coastal environmental conditions and litter type are major drivers of microbial functioning and responses to drought stress.
\end{abstract}

\section{Highlights}

- Poorly documented litter functioning in Mediterranean coastal environments is here investigated

- Coastal conditions smoothed litter type effect on certain microbial markers

- Pre-exposure to stress (coastal conditions) limited drought effect on microbial catabolic profiles

- Coastal areas should be considered when evaluating microbial functioning and responses to drought 


\section{1 | INTRODUCTION}

Successive variations in the earth's climate are established, but the warming observed since the 1950s is unprecedented. However, beyond increased global mean temperature, climate scientists (e.g. Giorgi \& Lionello, 2008; Pachauri et al., 2015) predict changes in the spatial and temporal distribution of precipitation as well as increased frequency and intensity of extreme events (e.g. heat waves, droughts, frosts, wild fires, storms and floods) worldwide. The Mediterranean basin, considered as a hotspot of biodiversity (Quézel \& Médail, 2003), has also been identified as one of the most prominent "hotspots" in future climate change projections (Giorgi \& Lionello, 2008). The Mediterranean context generates vulnerabilities to the coming climate changes: the Mediterranean climate is recognized as particularly drastic, being characterized by summer droughts and high temperatures, soils that are generally poor in organic matter (Kosmas, Danalatos, \& Gerontidis, 2000) and vegetation that is predominantly sclerophyllous, which limits organic matter transformation (Quézel \& Médail, 2003). This fundamental ecosystem process sustains major ecosystem services, such as primary production and biogeochemical cycles (Edwards, 2007). Soil microbial communities are key to this process, and their activities depend on environmental factors such as temperature, moisture, and the quantity and quality of litter inputs (Zimmer, 2002). All of these factors are to be altered by climate change and particularly by increased drought (Change, 2007).

Previous studies found that microbial communities frequently exposed to drought stresses are more resistant to the effects of drying/rewetting cycles than less exposed communities (Butterly, Bünemann, McNeill, Baldock, \& Marschner, 2009; Fierer \& Schimel, 2003; Schmitt, Glaser, Borken, \& Matzner, 2010). However, the stability of decomposer microbial communities after stress also depends on other factors that control community structure, such as litter quality and quantity (Classen et al., 2015; Loreau, 2010; Loreau et al., 2001; Wardle \& Jonsson, 2014). The diversity of plant species within litter mixtures is also thought to maximize the diversity of nutrient resources, which in turn favours microbial diversity and abundance (Brunel, Gros, Ziarelli, \& Farnet da Silva, 2017; Cuchietti, Marcotti, Gurvich, Cingolani, \& Pérez Harguindeguy, 2014; Prescott \& Grayston, 2013; Wu, Li, \& Wan, 2013). In other words, diversity begets diversity (Brunel et al., 2017;
Chapman \& Newman, 2010). Litter chemical diversity strongly influences the residence time of organic matter in soils and its adsorption on soil aggregates (Ekschmitt, Liu, Vetter, Fox, \& Wolters, 2005). Moreover, aromatics modify soil hydrophobicity and limit organic matter oxidation (Rimmer \& Abbott, 2011). Litter composition and transformation is thus supposed to further modify soil structure and physicochemical properties; consequently, deciphering environmental drivers of such processes is of main importance. However, which factor, climate or litter quality, plays a key role in the decomposition process is particularly difficult to determine because contrasting results have been found (e.g. Berg et al., 1993; Wall et al., 2008) showing that, over broad regional scales, climate conditions were likely to be the crucial factor controlling decomposer activities, whereas litter quality played a role at the local scale under similar climate conditions. In Mediterranean coastal environments, particular climate constraints are found: (a) wind regime inducing desiccation and drought stress; (b) sea spray exposure, which exacerbates stresses linked to water potential; and (c) high temperatures. This set of features typical of coastal conditions will be defined here as "coastal print" (Boukhdoud, Gros, Darwish, \& Farnet da Silva, 2016).

The objective of this study was to understand how microbial functioning in litter on the soil surface may be controlled by the "coastal print" and the type of litters. Two plant species commonly found in Mediterranean coastal and inland areas with contrasting functional traits were chosen: Pinus halepensis (a resinous species) and Pistacia lentiscus (a leafy species), and their admixture (50/50). Moreover, we aimed to investigate whether microbial responses to stress linked to water potential may be driven by pre-exposure to stress (coastal conditions) and/or litter type. We hypothesized that previous exposure to stresses linked to water potential (coastal environments) and/or litter type would shape microbial resistance to an additional stress. Thus, our experimental set-up consisted of mesocosms using litters from both inland and coastal areas, which were subjected or not (controls) to several drying/rewetting cycles. After a 3-month incubation, microbial communities were characterized using several indicators of microbial activity linked to litter mineralization (lignocellulolytic activities and basal respiration $[\mathrm{BR}])$, and the community level physiological profiles (CLPP) of bacterial and fungal communities were also analysed using Biolog Ecoplate and FF plates. Total organic carbon (TOC), nitrogen $(\mathrm{N})$ content measurement and solid-state nuclear magnetic resonance $\left({ }^{13} \mathrm{C}\right.$ NMR) were 
used to provide an overall chemical characterization of organic matter.

\section{2 | MATERIAL AND METHODS}

\subsection{Site description and litter sampling}

Two areas of around $30 \mathrm{~km}^{2}$ were chosen: (i) the coastal area was the peri-urban area of Marseille on the French Mediterranean coast $\left(43^{\circ} 12^{\prime} 38.80^{\prime \prime} \mathrm{N} ; 5^{\circ} 21^{\prime} 19.53^{\prime \prime} \mathrm{E}\right)$ and (ii) the inland area was near Aix en Provence at the Plateau de l'Arbois $\left(43^{\circ} 29^{\prime} 34.64^{\prime \prime} \mathrm{N} ; 5^{\circ} 19^{\prime} 48.72^{\prime \prime} \mathrm{E}\right)$ and the Massif de la Trévaresse $\left(43^{\circ} 38^{\prime} 31.54^{\prime \prime} \mathrm{N} ; 5^{\circ} 26^{\prime} 1.11^{\prime \prime} \mathrm{E}\right)$. The coastal and the inland areas were located, respectively, at $30 \mathrm{~m}$ and at around $30 \mathrm{~km}$ from the sea. These six sites (30 to $200 \mathrm{~m}$ in elevation) present similar exposure (south-eastern), slope (10 to $15 \%$ ) and soil type (Calcaric Leptosol according to IUSS Working Group WRB, 2006).

Each area included three independent sites (distance between sites $2 \mathrm{~km}$ at least). At each site, composite sampling was performed in January 2017 from litters (horizon Ol) of Pistacia lentiscus and Pinus halepensis. P. lentiscus is a thermophilic evergreen shrub with sclerophyllous leaves, which is highly tolerant of severe drought and calcareous soils that are typically poor in organic matter, and particularly widespread in seaside stony areas in the Mediterranean region (Garcia-Fayos \& Verdu, 1998). $P$. halepensis is a pioneer resinous species also widely found in xeric Mediterranean soils. P. halepensis and P. lentiscus are the two dominant species in both the coastal and inland areas under study. For each species and in each of the three sites $\left(500 \mathrm{~m}^{2}\right), 10$ samples of litter (around $50 \mathrm{mg}$ per sample) were collected using random quadrat sampling. Three composite samples of $0.5 \mathrm{~kg}$ were thus obtained for each species and for each area $(n=3)$. Consequently, to set up the mesocosm experiment, each set of three composite samples was used to prepare three mesocosms. Debris from other species, branches and seeds were removed carefully from each collection. Then, homogenized samples of each species and from each area were stored at $4{ }^{\circ} \mathrm{C}$ until mesocosm preparation.

\section{2 | Environmental parameter measurement}

Temperature, humidity, $\mathrm{pH}$, electrical conductivity (EC) and chloride ion $\left(\mathrm{Cl}^{-}\right)$concentration in litters from both areas were monitored over 1 year, at least every 2 months. Mean daily temperature was obtained using three USB temperature loggers (VOLTCRAFT, $100 \mathrm{~T}$, CONRAD, Haubourdin, France) placed at a depth of around $4 \mathrm{~cm}$ in litters from both coastal and inland areas. Litter extract from the three composite samplings of each area, 1:10 w/v (litter/ $\left.\mathrm{H}_{2} \mathrm{O}\right)$, was obtained after $30 \mathrm{~min}$ of shaking at $80 \mathrm{rpm}$ and a $30-\mathrm{min}$ equilibrium time. $\mathrm{pH}$ was measured with a Metrohm $744 \mathrm{pH}-$ meter, and $\mathrm{EC}$ and $\mathrm{Cl}^{-}$concentration were measured using an electrode from HI 9835 Multiparameter EC/TDS/ ${ }^{\circ} \mathrm{C} / \mathrm{NaCl}$ (HANNA Instruments, Limena, Italy). Litter moisture was determined after drying $\left(90^{\circ} \mathrm{C}\right)$ to a constant weight.

\subsection{Mesocosm preparation and experimental set-up}

Litter was placed in horticultural pots $(20 \times 20 \times 5 \mathrm{~cm})$ containing $25 \mathrm{~g}$ (dry weight, DW) of Pinus litter, Pistacia litter or a mixed Pinus/Pistacia litter (50/50, DW/DW) per mesocosm. A total of 36 mesocosms were prepared (36 mesocosms $=3$ composite samples from 3 sites $\times 3$ types of litter $\times 2$ sites [coastal and inland] $\times 2$ types of treatment [stress and control]). Litter was rehydrated to $60 \% \mathrm{WHC}$ (Qasemian, Guiral, \& Farnet, 2014) with sterilized water and the mesocosms were covered with pierced tin foil. The 36 mesocosms were preincubated for 15 days under temperature $\left(25^{\circ} \mathrm{C}\right)$ and WHC $(60 \%)$ conditions favourable to microbial growth. After this period of preincubation, a first set of 18 "control" mesocosms ( 3 mesocosms $\times 3$ types of litter [pure or mixed] $\times 2$ sites [coastal and inland]) was maintained under favourable conditions for 60 days $\left(25^{\circ} \mathrm{C}\right.$, $60 \%$ WHC). A second set of 18 mesocosms simulating drought stress was subjected to five drying/rewetting cycles. Each drying/rewetting cycle was composed of two steps: (a) a 7-day drying period at $35^{\circ} \mathrm{C}$ to reach a final water content close to $25 \%$ of humidity; and (b) a quick rewetting to recover $60 \% \mathrm{WHC}$, followed by a 7-day incubation period at $60 \% \mathrm{WHC}$ and $25^{\circ} \mathrm{C}$. After each drying period, thermodynamic water activity, $a_{w}$, was measured with a Hygropalm probe (Rotronic, Fisher Scientific, Illkirch, France) to assess the level of water potential stress achieved (Farnet, Qasemian, Gil, \& Ferré, 2013; Farnet-Da Silva, Ferré, Dupuy, de la Boussinière, \& Rébufa, 2017). Thermodynamic water activity is defined as the ratio of water vapour pressure in the system over pure water at constant pressure and temperature.

After incubation, a fraction of each sample was dried and ground prior to chemical analysis. All the experiments involving microbial analyses were immediately initiated and performed over 1 week.

\section{4 | Extracellular enzyme activities}

The lignocellulolytic activities in the litter were assessed. Cellulase activity was assayed using CarboxyMethylCellulose (CMC) $0.1 \%(\mathrm{w} / \mathrm{v})$ in $8 \mathrm{~mL}$ of sodium acetate buffer (50 mM, pH 5) added to $1 \mathrm{~g}$ of litter (dry weight) incubated 
for $4 \mathrm{~h}$ at $50^{\circ} \mathrm{C}$. Glucose content was quantified according to the Somogyi-Nelson method and absorption was read at $870 \mathrm{~nm}$ (Farnet, Qasemian, Guiral, \& Ferré, 2010). Tyrosinase activity (phenoloxidase activity) was based on the oxidation of L-DOPA to L-DOPA quinone $\left(\varepsilon^{\mathrm{M}}=3,400 \mathrm{M}^{-1} / \mathrm{cm}\right)$ following Saiya-Cork, Sinsabaugh, and Zak (2002). Briefly, L-DOPA $5 \mathrm{mM}$ in $6 \mathrm{~mL}$ of phosphate buffer $(50 \mathrm{mM}, \mathrm{pH} 6.5)$ was added to $1 \mathrm{~g}$ of litter (dry weight), which was incubated for $5 \mathrm{~h}$ at $37^{\circ} \mathrm{C}$. Enzyme activities were expressed as $\mu$ mole of product formed per hour per g dry weight.

\section{5 | Microbial basal respiration and substrate-induced respiration}

For each mesocosm, basal respiration was measured using $3 \mathrm{~g}$ DW equivalent of fresh litter placed in 117-mL glass jars. The glass jars were immediately sealed with hermetic rubber septa and incubated for $2 \mathrm{hr}$ at $23^{\circ} \mathrm{C}$. After incubation, $1 \mathrm{~mL}$ of air was sampled in the headspace with a syringe and injected into a gas chromatograph (Chrompack CHROM 3 - CP 9001, Agilent, Santa Clara, CA, USA) to analyse $\mathrm{CO}_{2}$ production. The gas chromatograph was equipped with a thermal conductivity detector and a packed column (Porapack, Chrompack, Agilent). The carrier gas helium flow was regulated at $60 \mathrm{~mL} / \mathrm{hr}^{-1}$. Ambient $\mathrm{CO}_{2}$ concentrations were subtracted from sampled $\mathrm{CO}_{2}$ concentrations and resulting values were adjusted at $22^{\circ} \mathrm{C}$ according to Ideal Gas Laws using a $\mathrm{Q}_{10}=2$.

Substrate-induced respiration (SIR) rates were estimated using a procedure from Anderson and Domsch (1978). For each mesocosm, three grams DW-equivalent of fresh litter were placed in 117-mL glass jars and amended with powdered glucose $\left(1,000 \mu \mathrm{g} \mathrm{C} \mathrm{g}^{-1}\right.$ soil), which was found to maximize the respiration rate in our litter in a preliminary assay (data not shown). One $\mathrm{mL}$ of air was sampled in the headspace with a syringe and injected into a gas chromatograph to analyse $\mathrm{CO}_{2}$ production for $1 \mathrm{hr}$ (see above). Substrate-induced respiration was converted into microbial biomass (MB) using the relation established by Beare, Neely, Coleman, and Hargrove (1990).

\section{6 | Microbial C-substrate utilization profiles and catabolic diversity}

The potential of cultivable microbial communities to oxidize different C-substrates was determined with two Biolog plates: EcoPlate and FF MicroPlate (Biolog, Hayward, CA, USA) using a procedure adapted from Garland and Mills (1991). Briefly, $4 \mathrm{~g}$ of dry litter was added to $100 \mathrm{~mL}$ of $0.1 \%$ sodium pyrophosphate sterile buffer in a $250-\mathrm{mL}$ flask and shaken for $2 \mathrm{hr}(80 \mathrm{rpm})$. One extraction from the litter of each mesocosm was performed. The litter suspension was diluted and standardized at optical density (OD) $595 \mathrm{~nm}=0.03$ with a sterile physiological solution $(\mathrm{NaCl}$ $0.85 \%) ; 125 \mu \mathrm{L}$ of microbial suspension were used to inoculate each well. The plates were incubated at $25^{\circ} \mathrm{C}$ for 5 days and microbial response was monitored by reading the absorbance at 590 and $490 \mathrm{~nm}$, respectively, for EcoPlate and FF plate, using a TECAN ${ }^{\circledR}$ spectrophotometer (Tecan Trading AG, Switzerland). The absorbance value for each well was blanked against the control well and negative absorbance values were set to zero. The minimum OD for a positive well was fixed at 0.25 for ECO and 0.15 for FF plates. The ODs after $48 \mathrm{hr}$ for ECO and FF plates were chosen according to the exponential phase of growth curves for all plates, for further comparison. Catabolic diversity was assessed using Shannon's index:

$$
H^{\prime}=-\sum_{i=1}^{N} p_{i} \log _{10} p_{i}
$$

where $\mathrm{p}_{\mathrm{i}}$ is the ratio of colour development of the $i^{\text {th }}$ well to the sum of colour development of all positive wells.

\section{7 | Litter chemical properties}

The litter chemical properties (solid-state ${ }^{13} \mathrm{C}$ NMR spectroscopy and $\mathrm{C} / \mathrm{N}$ ) were analysed at $\mathrm{t}=0$ (composite sample used for mesocosm preparation) and after the 3-month experiment. To determine the chemical composition of Pinus and Pistacia litters, total organic carbon (TOC) and nitrogen $(\mathrm{N})$ contents were analysed by combustion in an elemental analyzer (Flash EA 1112 series, ThermoScientific, Illkirch-Graffenstaden, France). The solid-state ${ }^{13} \mathrm{C}$ NMR spectra were obtained on a Bruker Avance III HD $-400 \mathrm{MHz}$ NMR spectrometer (Rheinstetten, Germany) operating at a ${ }^{13} \mathrm{C}$ resonance frequency of $100.7 \mathrm{MHz}$ and using a commercial Bruker double-channel probe (Rheinstetten, Germany). A single measurement was performed for each mesocosm. About $100 \mathrm{mg}$ of sample were placed in zirconium dioxide rotors of 4-mm outer diameter and spun at the magic angle spinning (MAS) rate of $10 \mathrm{kHz}$. The cross polarization (CP) technique was applied with a ramped $1 \mathrm{H}$-pulse starting at $100 \%$ power and decreasing to $50 \%$ during contact time (2 ms) to avoid Hartmann-Hahn mismatches. The experiments were performed at ambient temperature and $4 \mathrm{~K}$ scans were accumulated using a delay of $2.5 \mathrm{~s}$, giving an experimental time of $3 \mathrm{hr}$. The ${ }^{13} \mathrm{C}$ chemical shifts were referenced to tetramethylsilane and calibrated with a glycine carbonyl signal set at $176.5 \mathrm{ppm}$. The ${ }^{13} \mathrm{C}$ NMR spectra were divided into seven chemical shift regions according to Knicker and Lüdemann (1995); that is, alkyl C (0-45 ppm), methoxyl C or N-alkyl C (45-60 ppm), O-alkyl 
C (60-90 ppm), di-O-alkyl C (90-110 ppm), aromatic CC/aromatic C-H (110-140 ppm), aromatic C-O (phenols) (140-160 ppm) and carboxyl/amide C (160-190 ppm). Deconvolution of each spectrum was performed on DmFit 2011 to determine the relative intensity of each selected region (Massiot et al., 2002). It has to be noted that, although this could give a good outline of the bulk chemical composition of litters, some signal overlapping cannot be completely excluded and thus the assignment is not straightforward (Knicker, 2011; Knicker \& Lüdemann, 1995). In order to assess differences in litter chemical properties, we focused on three types of carbon components: (a) alkyl C (in fatty acids, amino acids or paraffinic structures), assumed to derive mainly from recalcitrant waxes, cutin, lipids or amino acids; (b) O-alkyl $\mathrm{C}$ and di-O-alkyl $\mathrm{C}$ assigned to labile carbohydrates; and (c) aromatic C-C/aromatic $\mathrm{C}-\mathrm{H}$ and aromatic $\mathrm{C}-\mathrm{O}$ (phenols), referring mainly to the recalcitrant fraction of organic matter (i.e., lignin and tannin compounds) (Cepáková \& Frouz, 2015; Knicker, 2011).

The alkyl C/O-alkyl C (A/O-A) ratio was calculated from the ${ }^{13} \mathrm{C}$ NMR data. It is widely used as a robust index to measure the extent of decomposition based on changes in litter chemical composition (Baldock et al., 1997; Dignac, Knicker, \& Kögel-Knabner, 2002; Li et al., 2015).

\subsection{Statistical analyses}

Three-way analyses of variance (ANOVAs) were performed on data from the 36 mesocosms, taking into account (a) environmental context (coast vs. inland, 18 mesocosms for each condition), (b) litter species (Pinus vs. Pistacia vs. mixed litter, 12 mesocosms for each condition) and (c) treatment type (control vs. stress, 18 mesocosms for each condition), and their interactions, followed by Fisher's least significant difference (LSD) post hoc test (XLSTAT software, Addinsoft, Paris, France). The normality and homogeneity of the variances were determined on the residuals from the regression model with the Shapiro-Wilk and Levene tests, respectively. Data were transformed to common logarithms, $\log _{10}$, when necessary to meet the requirements of normality and homogeneity of variance for ANOVA. When a two-way interaction was found between environmental context and treatment type or plant litter species, we separated data for each modality using a one-way ANOVA. Statistically significant $(\mathrm{p}<0.05)$ main effects and interactions were analysed further using Fisher's LSD test. Specific relationships between certain microbial indicators (lignocellulolytic activities, BR and MB) and chemical measurements $\left({ }^{13} \mathrm{C}\right.$ NMR C-groups, $\left.\mathrm{C} / \mathrm{N}\right)$ were tested using Pearson's correlation coefficients. The optical absorbance of each well in the ECO plate and FF plate (after $48 \mathrm{hr}$ incubation) was subjected to principal component analysis (PCA), considering each substrate as a variable. PCA was performed on correlation matrices obtained from Biolog ${ }^{\circledR}$ data to provide an ordination of the microbial $\mathrm{C}$-substrate utilization profiles, which were plotted in one and two dimensions, respectively, based on the mean scores (three mesocosms) of the first two principal components (PC). A first PCA was performed on control data to test the effect of the environmental context and litter type and another PCA was performed taking into account the treatment effect (stress vs. control) on microbial catabolic structures. Statistical analyses were performed with XLSTAT-Pro 7.5 (Addinsoft).

\section{3 | RESULTS}

\subsection{Environmental parameters over a 1-year monitoring period}

To underline the contrasting environmental conditions between inland and coastal areas, certain environmental parameters were monitored throughout 1 year. As expected, contrasting climate conditions were found between coastal and inland areas. The annual mean temperature was higher in the coastal area $\left(21.2\right.$ and $18.4^{\circ} \mathrm{C}$ from coastal and inland sites, respectively). The maximal temperature and humidity recorded in the field were $37.7^{\circ} \mathrm{C}, 48 \%$ and $44.5^{\circ} \mathrm{C}, 21 \%$ in inland and coastal area, respectively. Electrical conductivity and $\mathrm{Cl}^{-}$concentrations were higher in coastal litter, where they reached a maximum of $1,697 \mu \mathrm{S} / \mathrm{cm}$ and $3.05 \%$ as compared to a maximum of $480 \mu \mathrm{S} / \mathrm{cm}$ and $0.85 \%$ in the inland sites.

\section{2 | Litter chemistry}

Litter chemical properties (solid-state ${ }^{13} \mathrm{C}$ NMR and $\mathrm{C} / \mathrm{N}$ ) at $\mathrm{t}=0$ (composite sample used for mesocosm preparation) and after the 3-month experiment in mesocosms are shown in Tables 1 and 2, respectively. Some examples of the spectra of the analysis of the litter of both plant species from both environmental contexts at $\mathrm{t}=0$ are given as Figure $\mathrm{S} 1$.

The ${ }^{13} \mathrm{C}$ NMR spectra of litter composite samples showed that carbohydrates (di-O-alkyl C + O-alkyl C) were the major organic compounds of litters and were higher in $P$. halepensis than in P. lentiscus litters (Table 1 and Figure S1). Furthermore, for each plant species, a higher content of di-O-alkyl C + O-alkyl C was found for litters from the inland area and this was also observed after the 3-month experiment (Table 2 and Table S2).

Alkyl C was negatively correlated with di-O-alkyl C $+\mathrm{O}$-alkyl $\mathrm{C}$ content $(\mathrm{r}=-0.934, \mathrm{p}<0.0001)$. More specifically, whatever the litter's environmental context of origin (inland or coastal), a higher content of alkyl $\mathrm{C}$ was found in $P$. lentiscus litters and this difference was more marked at 
TA B L E 1 Litter chemical properties: carbon content (\%C), nitrogen content $(\% \mathrm{~N}), \mathrm{C} / \mathrm{N}, \mathrm{C}$-groups defined from ${ }^{13} \mathrm{C}$ NMR spectra, and $\mathrm{pH}$ measured on the three types of litters (Pinus halepensis, Pistacia lentiscus, and the equitable admixture of both plant species) collected from both environmental contexts (inland and coastal areas) at $\mathrm{t}=0$ (prior to mesocosm set-up). These analyses represent a single value for a composite sample obtained from three sampling sites from either a coastal or inland area

\begin{tabular}{|lrrrrr|} 
& \multicolumn{2}{c}{ Pinus halepensis } & & \multicolumn{2}{c|}{ Pistacia lentiscus } \\
\cline { 2 - 3 } \cline { 6 - 6 } \cline { 6 - 6 } Alkyl C & Inland & Coast & & Inland & Coast \\
\hline di-O-alkyl C + O-alkyl C & 48.98 & 46.29 & 47.96 & 44.00 \\
\hline Methoxyl C & 6.46 & 6.71 & 5.55 & 5.24 \\
\hline Aromatics+Phenols & 15.68 & 14.10 & & 15.55 & 16.23 \\
\hline Carboxyl C & 3.89 & 4.25 & 5.92 & 4.90 \\
\hline Alkyl C/O-alkyl C & 0.61 & 0.74 & 0.69 & 0.87 \\
\hline C $(\%)$ & 48.09 & 43.81 & 39.01 & 49.31 \\
\hline N $(\%)$ & 1.12 & 1.31 & 0.98 & 1.27 \\
\hline C/N & 42.89 & 33.55 & 39.92 & 38.80 \\
\hline pH & 6.27 & 6.48 & 6.98 & 6.80 \\
\hline
\end{tabular}

the end of the 3-month experiment (Table 2 and Table S2). Moreover, for each plant species, a higher content of alkyl C was found in litters from the coastal area (Table 1, Table 2, and Table S2).

The A/O-A ratio (alkyl C/O-alkyl C) was positively correlated with alkyl $\mathrm{C}(\mathrm{r}=-0.963, \mathrm{p}<0.0001)$ and negatively correlated with di-O-alkyl C + O-alkyl C $(\mathrm{r}=-0.978$, $\mathrm{p}<0.0001)$. The A/O-A ratio and alkyl $\mathrm{C}$ followed a similar pattern; that is, higher values for litters from coastal areas, indicating a higher level of decomposition. This ratio was also higher for $P$. lentiscus than $P$. halepensis litters (Table 1, Table 2 and Table S2).

At $\mathrm{t}=0$, the lowest content of aromatics+phenols was found in coastal litters of P. halepensis (14.10\%), whereas the highest content $(16.23 \%)$ was observed in coastal litters of $P$. lentiscus (Table 1). This indicated a potential interaction effect between the environmental context (coast vs. inland) and litter type. This was confirmed after the 3-month incubation (Table 2 and Table S2).

At $\mathrm{t}=0$ (Table 1) or after the 3-month incubation, $P$. halepensis litters showed higher $\mathrm{N}$ (\%) than $P$. lentiscus litters whatever the environmental context. Moreover, for each plant species, higher N (\%) was found for litters from the coastal area $(F=23.135$, $\mathrm{p}<0.001$ and $\mathrm{F}=24.994, \mathrm{p}<0.001$ for litters of $P$. halepensis and $P$. lentiscus, respectively) (Table 1, and Table S2).

\section{3 | Indicators of microbial activity}

Considering lignocellulolytic activities, only cellulases were influenced by the interaction between environmental context and type of litter $(\mathrm{F}=7.71, \mathrm{p}<0.01)$. This interaction also had a significant effect on basal respiration $(\mathrm{F}=5.47$, $\mathrm{p}<0.05)$. Conversely, neither MB nor catabolic index of diversity (Shannon-Weaver index, $\mathrm{H}^{\prime}$ ) calculated from Biolog data was influenced by this interaction (Table S1).

Patterns were identical for both cellulases and BR (Figure 1a,b). For inland litters, higher cellulase activities and $\mathrm{BR}$ values were found in $P$. halepensis litters than in $P$. lentiscus and mixed litters $(\mathrm{F}=15.39, \mathrm{p}<0.001$ and $\mathrm{F}=9.79, \mathrm{p}<0.01$ for cellulases and BR, respectively). The values were not significantly different between $P$. lentiscus and mixed litters. For coastal litters, however, there were no differences in these microbial indicators whatever the litter type (i.e., $P$. halepensis or P. lentiscus or mixed litters). The aromatic fraction (aromatics+phenols) was also affected by the interaction between the environmental context and litter type (Table S2). The aromatic fraction followed the opposite trend compared to these microbial indicators (cellulases and BR) as there were no significant differences between the three litter types from the inland area, whereas for coastal litters, higher aromatics+phenols content was found in P. lentiscus litters $(\mathrm{F}=14.752, \mathrm{p}<0.001)$.

No significant correlations between litter chemistry and microbial indicators were found for coastal litters. On the other hand, for inland litters, significant correlations were found between certain chemical measurements (N (\%), (diO-alkyl C + O-alkyl C), alkyl C) and microbial indicators (cellulases and $\mathrm{BR}$ ). More precisely, positive correlations were found between (di-O-alkyl C + O-alkyl C) and both cellulases $(r=0.642, p<0.01)$ and $B R(r=0.799$, $\mathrm{p}<0.0001)$ ). In addition, $\mathrm{N}(\%)$ was positively correlated with cellulases $(r=0.729, p<0.001)$. Alkyl $C$ was negatively correlated with these microbial indicators $(r=-0.596$, $\mathrm{p}<0.01$ and $\mathrm{r}=-0.748, \mathrm{p}<0.001$ for cellulases and BR respectively). No significant correlations were found between the aromatics+phenols and these indicators of microbial activity.

To better understand how the environmental context (coast vs. inland) and/or litter type shaped microbial functioning, a principal component analysis (PCA) was performed using the carbon utilization profiles of bacterial and fungal communities (Figure 2a,b). We considered the two first principal components (PC1 and PC2), accounting for $50.54 \%$ and $42.46 \%$ of the variance for FF and ECO plates, respectively (Table 3). The projections showed a marked discrimination of catabolic structures depending on the environmental context according to PC1 (40.6\%) and to PC2 (12.1\%) for fungal (Figure 2a) and bacterial communities (Figure 2b), respectively. The effect of litter type was also 


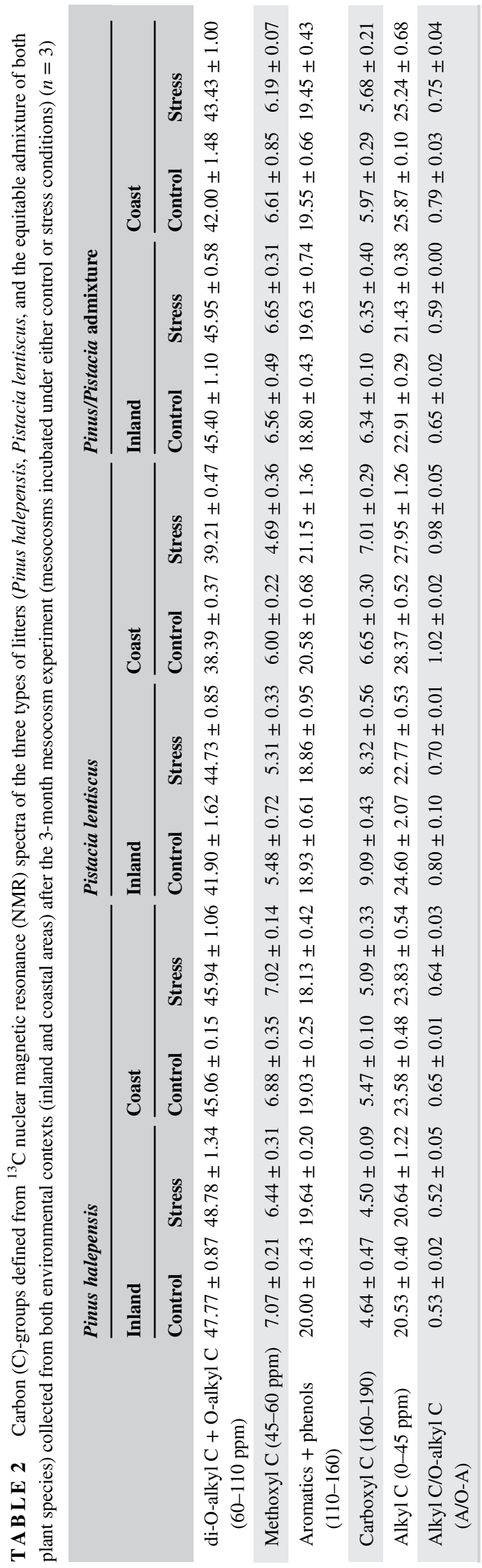

(a)

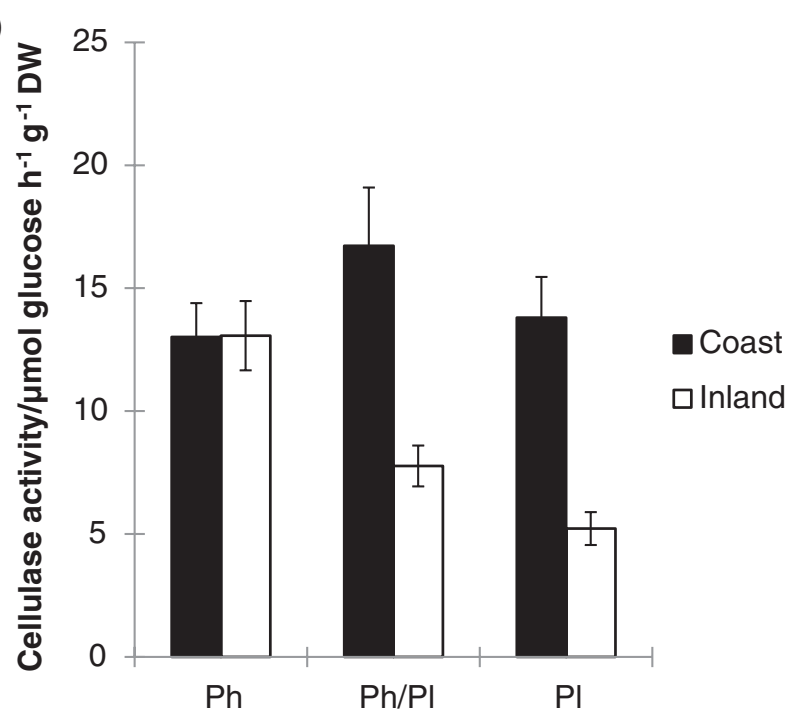

(b)

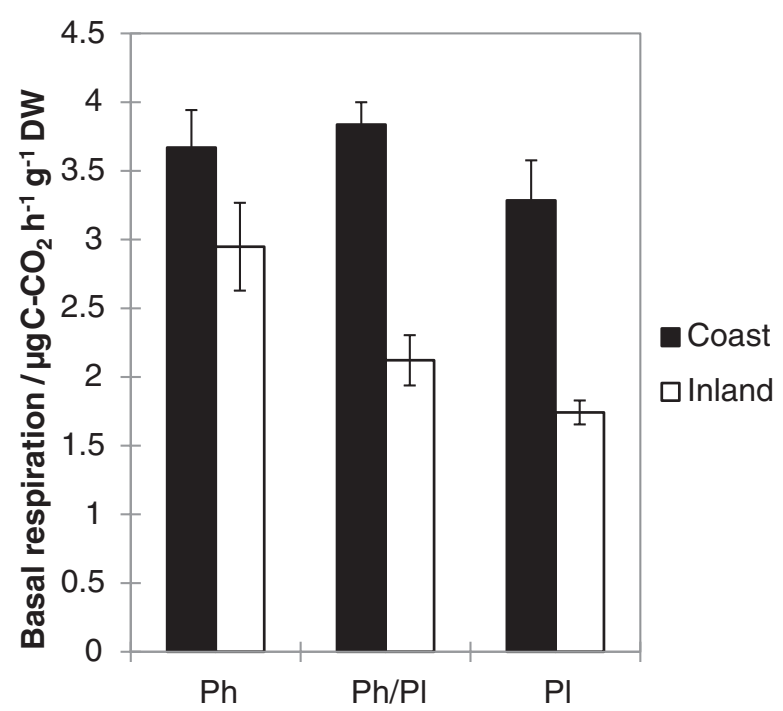

F I G URE 1 Cellulase (a) and basal respiration (b) in mesocosms after a 3-month incubation in litters of Pinus halepensis $(\mathrm{Ph})$, Pistacia lentiscus $(\mathrm{Pl})$ or an admixture $(50 / 50)$ of both litters $(\mathrm{Ph} / \mathrm{Pl})$ from inland (white bars) and coastal (black bars) areas $(n=3)$. Bars represent standard error

revealed for fungal communities because projections of $P$. lentiscus litters were always discriminated from the two other litter types ( $P$. halepensis and mixed litters) according to PC2 $(9.96 \%)$. This result was also observed for bacterial catabolic structures in litter from the coastal sites according to PC1 (30.35\%), but not in that from the inland sites.

These catabolic structures should be considered together with the catabolic diversity index (Shannon-Weaver index, $\mathrm{H}^{\prime}$ ). ANOVA (Table $\mathrm{S} 1$ ) indeed showed a significant effect of the environmental context on $\mathrm{H}^{\prime}$ for both fungal and bacterial communities. For bacterial communities, this index was higher in litters from coastal area $(F=4.054$, 

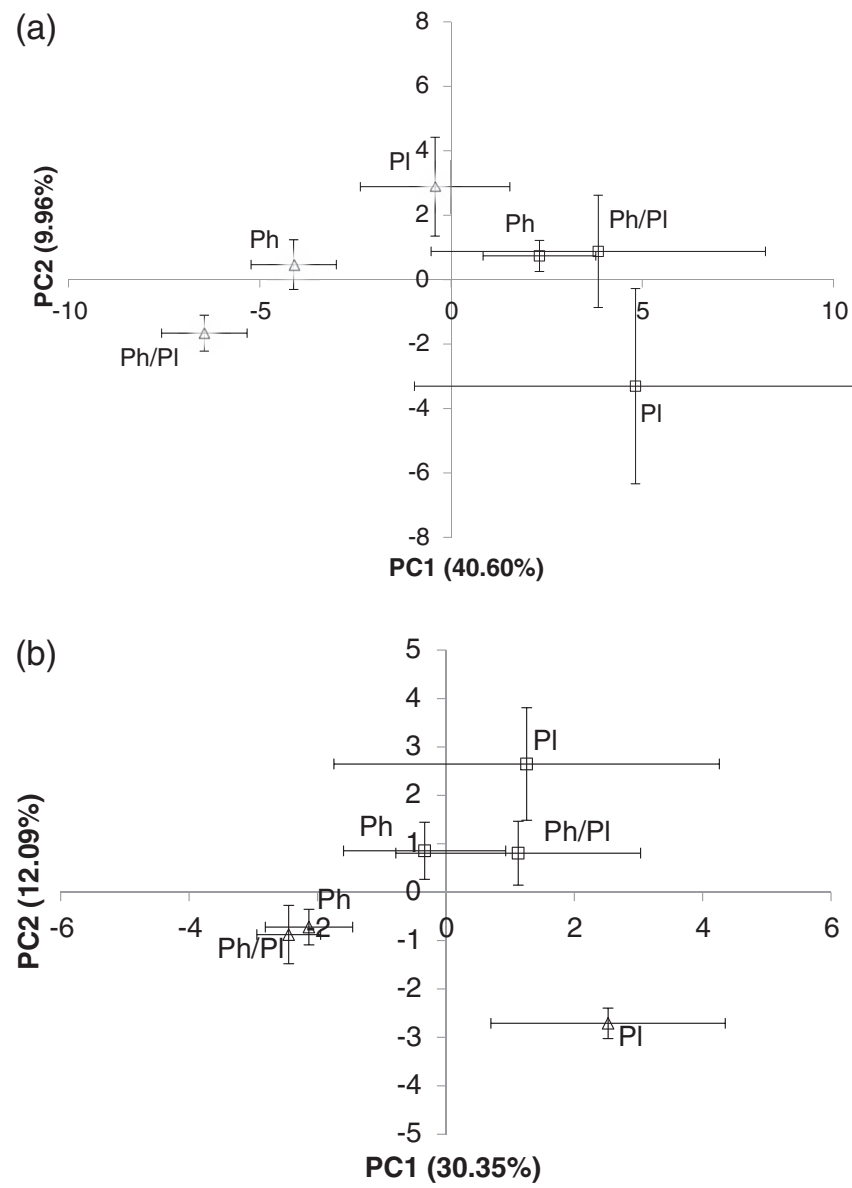

F I G URE 2 Principal component analysis (PCA) from FF (a) and ECO (b) plate substrate utilization profiles after a 3-month incubation in litters of Pinus halepensis $(\mathrm{Ph})$, Pistacia lentiscus $(\mathrm{Pl})$ or an admixture (50/50) of both litters ( $\mathrm{Ph} / \mathrm{Pl})$ from inland (squares) and coastal (triangle) areas. Only control mesocosms are considered. Each point represents the barycenter of three mesocosms $(n=3)$

$\mathrm{p}<0.05)$, whereas for fungal communities, higher $\mathrm{H}^{\prime}$ was found in litters from the inland area $(F=5.715, \mathrm{p}<0.05)$. This shows that the coastal print affected the catabolic diversity index of fungal and bacterial communities differently.

\subsection{Responses to drought stress}

A treatment effect on BR was detected (Table S1). After the 3-month experiment, higher BR was found for the stressed mesocosms $(F=6.029, \mathrm{p}<0.05)$. Moreover, drought stress had an effect on almost all the considered chemical properties except the aromatics+phenols fraction (Table S2, data shown in Table 2).

No effect of the interaction between treatment (control vs. stress) and the environmental context (coast vs. inland) was detected for any microbial indicator or chemical property (Tables S1 and S2), except for the bacterial catabolic diversity index $\left(\mathrm{ECO} \mathrm{\textrm {H } ^ { \prime }}\right)$. For the control, no significant difference was found in $\mathrm{ECO} \mathrm{H}^{\prime}$ between coastal and inland litters, whereas after stress, ECO $\mathrm{H}^{\prime}$ was significantly higher in coastal than inland litters $(\mathrm{p}<0.05)$.

A stress effect was observed both on tyrosinase activity and on MB, depending on litter type (Table S1). For tyrosinases, higher activities were found after stress in the admixture of litters compared to the control treatment $(\mathrm{p}<0.01)$. Moreover, no significant difference in tyrosinase activity was found between the three types of litter under stress conditions (Figure 3a). For MB (Figure 3b), after stress, it increased in $P$. lentiscus litters $(\mathrm{p}<0.01)$, decreased in mixed litters $(\mathrm{p}<0.001)$ and remained constant in P. halepensis litter ( $\mathrm{p}>0.05)$ (Figure 3b).

A PCA was performed on carbon utilization profiles of bacterial and fungal communities to examine whether the effect of drought stress on microbial catabolic potential depends on litter type and/or the environmental context. We considered the two first principal components (PC1 and PC2), accounting for $43.07 \%$ and $58 \%$ of the variance for FF and ECO plates, respectively (Table 4). For bacterial communities, PCA revealed that the catabolic profiles of inland litter were considerably modified after stress (Figure 4b). In contrast, for litter from the coastal sites, stress smoothed variations in catabolic structures whatever the litter type. After stress treatment, all catabolic structures were very similar

T A B L E 3 Eigenvalues from the principal component (PC) analysis obtained from FF and Ecoplate Biolog data on microbial catabolic profiles of soil in control mesocosms

\begin{tabular}{|c|c|c|c|c|c|c|}
\hline & PC1 & PC2 & PC3 & PC4 & PC5 & PC6 \\
\hline \multicolumn{7}{|l|}{ FF plate } \\
\hline Eigenvalue & 17.354 & 9.160 & 7.787 & 5.562 & 4.975 & 4.424 \\
\hline Cumulative $\%$ & 40.603 & 50.559 & 59.023 & 65.068 & 70.477 & 75.286 \\
\hline \multicolumn{7}{|l|}{ ECO plate } \\
\hline Percentage of variance explained & 30.352 & 12.086 & 10.867 & 10.228 & 7.147 & 6.286 \\
\hline Cumulative \% & 30.352 & 42.438 & 53.305 & 63.534 & 70.681 & 76.967 \\
\hline
\end{tabular}


(a)

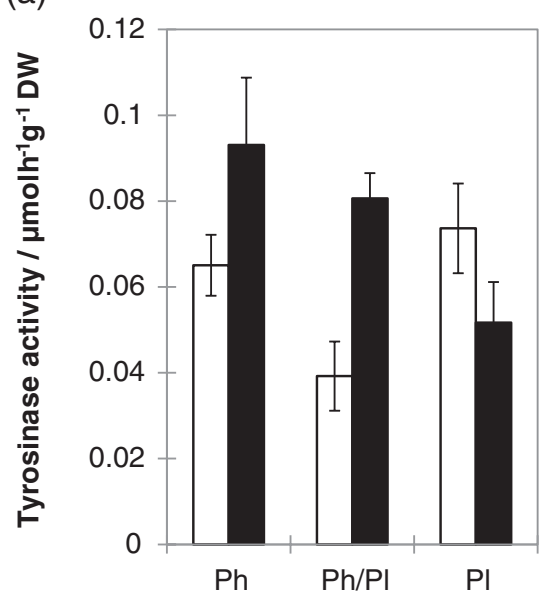

(b)

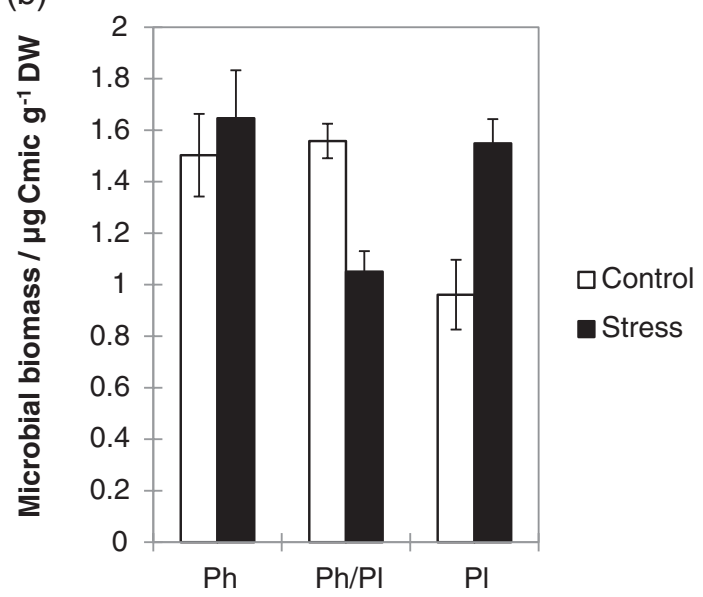

F I G U RE 3 Tyrosinase (a) and active microbial biomass (b) in mesocosms after a 3-month incubation in litters of Pinus halepensis $(\mathrm{Ph})$, Pistacia lentiscus $(\mathrm{Pl})$ or an admixture (50/50) of both litters $(\mathrm{Ph} / \mathrm{Pl})$ from control (white bars) and stress treatment (black bars) mesocosms $(n=3)$. Bars represent standard error

(Figure 4b). A litter effect was still observed, even after stress, for litters from the inland area as the catabolic structures in P. lentiscus were always strongly discriminated from those of the two other litter types.
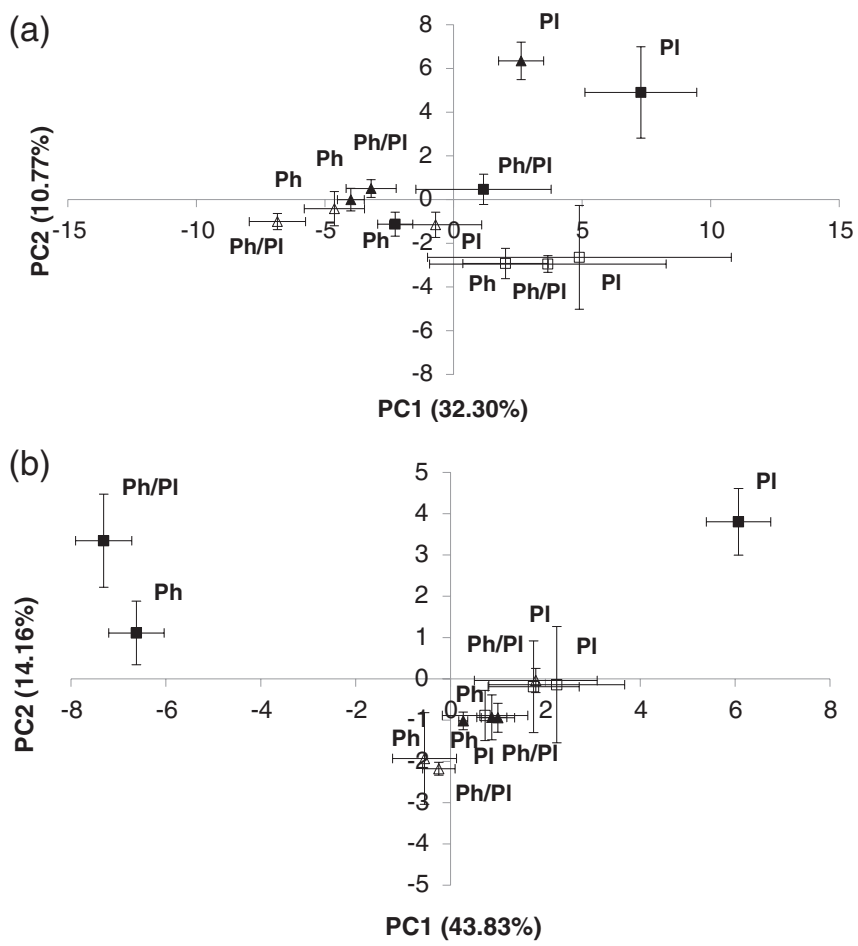

F I G URE 4 Principal component analysis (PCA) from FF (a) and ECO (b) plate substrate utilization profiles after a 3-month incubation in litters of Pinus halepensis (Ph), Pistacia lentiscus (Pl) or an admixture (50/50) of both litters $(\mathrm{Ph} / \mathrm{Pl})$ from inland (squares) and coastal (triangle) areas subjected to both treatments: Control (white) versus stress (black). Each point represents the barycenter of 3 mesocosms $(n=3)$

For fungal communities, a stress effect was also revealed in litters from both environmental contexts. This effect depended on litter type. The catabolic profiles in P. lentiscus litters from both inland and coastal areas were more impacted by stress than the two other litter types. It is noteworthy that the stress effect was more pronounced for litter from the inland sites, as revealed by the stronger variations in fungal and bacterial catabolic structures between control and stressed mesocosms for the three types of litter (Figure 4a,b)

T A B LE 4 Eigenvalues from the principal component (PC) analysis obtained from FF and Ecoplate Biolog data on microbial catabolic profiles of soil in control and stressed mesocosms

\begin{tabular}{|c|c|c|c|c|c|c|}
\hline & PC1 & PC2 & PC3 & PC4 & PC5 & PC6 \\
\hline Eigenvalue & 30.035 & 10.017 & 6.193 & 5.503 & 4.747 & 3.118 \\
\hline Cumulative \% & 32.296 & 43.067 & 49.726 & 55.644 & 60.748 & 64.101 \\
\hline \multicolumn{7}{|l|}{ ECO plate } \\
\hline Percentage of variance explained & 43.825 & 14.156 & 6.957 & 5.604 & 4.701 & 4.014 \\
\hline Cumulative $\%$ & 43.825 & 57.981 & 64.939 & 70.542 & 75.243 & 79.257 \\
\hline
\end{tabular}




\section{4 | DISCUSSION}

Our study showed that climate conditions and water potential stresses varied between the coastal and inland areas, revealing a "coastal print"; that is, more intense summer climate conditions (higher maximal temperature in summer, a lower $\%$ of humidity) as well as a higher osmotic stress (high conductivity and chloride ion \%). The environmental context (coastal or inland) also influenced litter chemical composition of $P$. lentiscus or $P$. halepensis. A higher A/O-A ratio, alkyl $\mathrm{C}$ and $\mathrm{N}$ (\%) with lower di-O-alkyl C + O-alkyl C observed for coastal litters may indicate a higher degree of degradation compared to inland litters (Baldock et al., 1997; Dignac et al., 2002; Li et al., 2015). This may be surprising because more drastic climate conditions in coastal area, especially drought stress, may have hindered decomposition (Allison et al., 2013; Santonja et al., 2017). On the other hand, temperature is considered to enhance litter decomposition by stimulating microbial decomposer enzymatic activities (Bond-Lamberty \& Thomson, 2010; Knorr, Holland, House, \& Prentice, 2005). Thus, responses of microbial decomposers to environmental conditions rely on a trade-off between temperature and drought because both could affect microbial physiology and community composition, and this trade-off depends on specific climatic thresholds of a given ecosystem (Prescott, 2010; Sardans \& Peñuelas, 2013; Sheik et al., 2011).

Community-level physiological profiles (CLPP) in our study corroborate these concepts, because after incubation under favourable conditions of temperature and humidity (control mesocosms), we observed distinct catabolic profiles for both bacterial and fungal communities of each plant species litter according to the environmental context (coast vs. inland). In addition, it was noted that the observed differences in chemical composition between coastal and inland litters may also result from plant responses to climate stress experienced in coastal conditions. A growing number of studies are showing that drastic climate conditions may induce changes in plant metabolism, affecting the chemical composition of plant litter (Sardans \& Peñuelas, 2013). Our results corroborate those of Allison et al. (2013), who found differences in initial litter chemistry of field plots subjected to drought stress compared to control plots. Litters derived from drought plots had a lower content of cellulose and hemicellulose and a higher content of lignin and lipids. Recently, Suseela and Tharayil (2018) showed how climate stress (high temperature and drought either alone or in combination) may lead to increased content of recalcitrant compounds, including lignin, suberin and cuticle within the plant tissue matrix, affecting, ultimately, litter chemical properties. Furthermore, our study showed significant chemical differences according to litter species whatever the environmental context. Litters of $P$. lentiscus were of relatively lower quality (higher content of alkyl C, lower content of carbohydrates (di-O-Alky C + O-Alkyl C) and $\mathrm{N}(\%)$ ) compared to litters of $P$. halepensis. This is in line with the study of Cepáková and Frouz (2015), who, through a comparative analysis of ${ }^{13} \mathrm{C}$ NMR data for litters from conifers, herbs, broadleaved species and evergreen shrubs, found that litters of evergreen shrubs had higher aliphatic contents than those of conifers. Differences in litter chemical properties led to variations in certain indicators of microbial activity (cellulase enzymatic activities and basal respiration) but only for litters from the inland area. More specifically, $P$. halepensis litters, characterized by higher contents of carbohydrates and $\mathrm{N}(\%)$ and lower content of Alkyl C, exhibited higher cellulase activity and basal respiration. Thus, one of our major findings reveals that coastal conditions (i.e. coastal print) have smoothed the effect of litter chemical differences on these microbial indicators.

The admixture of litters yielded a non-additive effect for cellulase and respiratory activities for litters from the inland area. In a study investigating the influence of oak occurrence on soil microbial functioning in pine stands, Brunel et al. (2017) reported that the litter mixing effect on decomposers' activities depended on tree species identity. They reported an additive effect was found with evergreen species (i.e. Quercus ilex), whereas a synergistic non-additive effect was obtained with $Q$. pubescens. We found here that the effect of litter admixture depended on the environmental context (coast vs. inland). Specifically, cellulase and respiratory activities for the Pinus/Pistacia admixture were not significantly different from those of monospecific litters, showing that coastal conditions smoothed the non-additive effect observed for inland litters. Among the few studies that attempted to explore how the litter-mixing effect may vary between habitats or ecosystems, Jonsson and Wardle (2008) found that the non-additive effect varies widely across environmental gradients.

PCA analysis revealed that the catabolic structures of bacterial communities were mainly structured by litter type (P. halepensis vs. P. lentiscus vs. Pinus/Pistacia admixture), whereas those of fungal communities were mainly influenced by the environmental conditions (coast vs. inland). One explanation is that bacteria are connected to their immediate surroundings (i.e. micro-niches) with very specific conditions (e.g. $\mathrm{pH}$ and nutrient availability), which may differ from the average properties of their environmental matrix (Urbanová et al., 2011; Vos, Wolf, Jennings, \& Kowalchuk, 2013). They also require water films for motility and substrate diffusion (Evans \& Wallenstein, 2012). On the other hand, mycelium-forming fungi have the ability to create mycelial cord networks that ramify at the soil-litter interface, making nutrient resources 
available over wide surface areas (Boddy, Hynes, Bebber, \& Fricker, 2009).

This study also set out to decipher the potential impacts of pre-exposure to stress (coastal environmental constraints; i.e. coastal print) and litter type (monospecific or mixed litter) on microbial responses to a drought stress. Certain microbial indicators (tyrosinase activities and $\mathrm{MB}$ ) were modified by drought stress depending on litter type. Higher tyrosinase activities and a lower MB were found in the stressed admixture of litters than under control conditions. Thus, because tyrosinases (phenoloxidase activities) mainly stem from fungal communities, drought stress is likely to favour these communities. Fungi may be more tolerant of drought stresses (fungal hyphae can transfer moisture from water-filled micropores) than bacteria, as described above. Water potential stress can reportedly reduce microbial growth yields, as described by Pesaro, Nicollier, Zeyer, and Widmer (2004), who found that MB remains depressed for at least 1 month after a severe drying/rewetting cycle.

It is noteworthy that pre-exposure to stress (coastal print) controlled the drought effect on microbial catabolic profiles for both bacterial and fungal communities. Variations in the catabolic structure of bacterial communities from the coastal sites after stress were smoothed, whereas those from the inland sites were strongly modified. Specific coastal conditions may have selected microorganisms more tolerant of stresses induced by drying/rewetting cycles. Evans and Wallenstein (2014) found that a decade of exposure to more frequent drying/rewetting stress resulted in a greater proportion of taxa exhibiting a stress-tolerant strategy, whereas communities exposed to a non-modified precipitation regime contained a greater abundance of pulse- or drought-sensitive organisms. Here, drought stress had a greater impact on catabolic profiles of inland communities than coastal communities and this is consistent with the notion that microbial communities not previously exposed to drying/rewetting events are less resistant to this type of stress (Bouskill et al., 2013). Modifications in fungal catabolic structures after stress were also shaped by litter type. The catabolic structures of $P$. lentiscus litters were strongly modified and markedly distinguished from the two other litter types. This litter type effect was also observed on bacterial catabolic structures but only for inland litters. For coastal litters, bacterial catabolic structures after stress were similar whatever the litter type. Thus, the coastal print smoothed also the effect of litter type, considering the responses of bacterial catabolic structures to stress. Furthermore, a higher bacterial catabolic diversity index, $\mathrm{ECO} \mathrm{H}^{\prime}$, was found after stress treatment for coastal litters. One could expect that stress induced by drying/rewetting cycles may reduce bacterial diversity by selecting microorganisms more adapted to this kind of stress. On the other hand, microbial diversity may alternatively increase as a result of temporal heterogeneity of the soil environment (here moisture fluctuation in litters through drying/rewetting cycles), favouring species coexistence (Fierer, Schimel, \& Holden, 2003; McLean \& Huhta, 2000).

Responses of microbial communities in litter to drought stress have indirect effects on soil properties because variations in microbial abundance and community composition, such as those induced by drought stress, modify yields of litter decomposition (Allison et al., 2013). The potential of microbial communities to maintain litter transformation yields is indeed crucial for organic matter translocation to the soil. This study revealed that coastal conditions, such as litter type, are major drivers of microbial functioning and responses to stress.

\section{5 | CONCLUSION}

In this study we evidenced that litter type (through species identity and litter admixture) is a major factor controlling microbial functioning in inland environments. However, the environmental constraints particular to coastal environments smoothed this litter-type effect on microbial decomposers. Here, we found that previous exposure to coastal environmental constraints mitigated the effect of an additional drought stress applied under laboratory conditions. Studies using climatic gradients in natura are highly recommended in order to simulate more intense aridity. Our findings reveal that poorly documented coastal environments should be accounted for in order to enhance our capacity to predict functional and microbial community responses under climate changes, and their consequences for ecosystem functioning and stability.

\section{ACKNOWLEDGEMENTS}

This research was financially supported by a $\mathrm{PhD}$ grant from Labex OT-MED, ANR 11 LABX-0061, funded by the French Government Investissements d'Avenir Program of the French National Research Agency (ANR) through an A*MIDEX project (ANR-11-IDEX-0001-02) and the Provence Alpes Côte d'Azur Region (France), and by funding from Labex OT-MED, the Fédération de Recherche ECCOREV (Ecosystèmes Continentaux et Risques Environnementaux), and BIODIVMEX from Program MISTRAL. The authors would like to thank the Regional Center of Forest Property (CRPF) for their contribution and Mrs Marjorie Sweetko for English language editing. We are grateful to Mrs Tiphany Bouriaud and Mrs Lisa Foli for their technical support. The two anonymous reviewers are acknowledged for their helpful and constructive comments. 


\section{DATA AVAILABILITY STATEMENT}

The data that support the findings of this study are available from the corresponding author upon reasonable request.

\section{REFERENCES}

Allison, S. D., Lu, Y., Weihe, C., Goulden, M. L., Martiny, A. C., Treseder, K. K., \& Martiny, J. B. H. (2013). Microbial abundance and composition influence litter decomposition response to environmental change. Ecology, 94, 714-725.

Anderson, J. P. E., \& Domsch, K. H. (1978). A physiological method for the quantitative measurement of microbial biomass in soils. Soil Biology and Biochemistry, 10, 215-221.

Baldock, J. A., Oades, J. M., Nelson, P. N., Skene, T. M., Golchin, A., \& Clarke, P. (1997). Assessing the extent of decomposition of natural organic materials using solid-state 13C NMR spectroscopy. Soil Research, 35, 1061.

Beare, M. H., Neely, C. L., Coleman, D. C., \& Hargrove, W. L. (1990). A substrate-induced respiration (SIR) method for measurement of fungal and bacterial biomass on plant residues. Soil Biology and Biochemistry, 22, 585-594.

Berg, B., Berg, M. P., Bottner, P., Box, E., Breymeyer, A., De Anta, R. C., ... Kratz, W. (1993). Litter mass loss rates in pine forests of Europe and Eastern United States: some relationships with climate and litter quality. Biogeochemistry, 20, 127-159.

Boddy, L., Hynes, J., Bebber, D. P., \& Fricker, M. D. (2009). Saprotrophic cord systems: dispersal mechanisms in space and time. Mycoscience, 50, 9-19.

Bond-Lamberty, B., \& Thomson, A. (2010). Temperature-associated increases in the global soil respiration record. Nature, 464, 579-582.

Boukhdoud, N., Gros, R., Darwish, T., \& Farnet da Silva, A. M. (2016). Effect of agricultural practices and coastal constraints on soil microbial functional properties in Mediterranean olive orchards: Soil properties in Mediterranean olive orchards. European Journal of Soil Science, 67, 470-477.

Bouskill, N. J., Lim, H. C., Borglin, S., Salve, R., Wood, T. E., Silver, W. L., \& Brodie, E. L. (2013). Pre-exposure to drought increases the resistance of tropical forest soil bacterial communities to extended drought. The ISME Journal, 7, 384-394.

Brunel, C., Gros, R., Ziarelli, F., \& Farnet da Silva, A. M. (2017). Additive or non-additive effect of mixing oak in pine stands on soil properties depends on the tree species in Mediterranean forests. Science of the Total Environment, 590-591, 676-685.

Butterly, C. R., Bünemann, E. K., McNeill, A. M., Baldock, J. A., \& Marschner, P. (2009). Carbon pulses but not phosphorus pulses are related to decreases in microbial biomass during repeated drying and rewetting of soils. Soil Biology and Biochemistry, 41, 1406-1416.

Cepáková, S., \& Frouz, J. (2015). Changes in chemical composition of litter during decomposition: a review of published ${ }^{13} \mathrm{C}$ NMR spectra. Journal of Soil Science and Plant Nutrition, 15, 805-815.

Change, I. P. O. C. (2007). Climate change 2007: The physical science basis. Agenda, 6, 333.

Chapman, S. K., \& Newman, G. S. (2010). Biodiversity at the plantsoil interface: Microbial abundance and community structure respond to litter mixing. Oecologia, 162, 763-769.

Classen, A. T., Sundqvist, M. K., Henning, J. A., Newman, G. S., Moore, J. A. M., Cregger, M. A., ... Patterson, C. M. (2015). Direct and indirect effects of climate change on soil microbial and soil microbial-plant interactions: What lies ahead? Ecosphere, 6, art, 130.

Cuchietti, A., Marcotti, E., Gurvich, D. E., Cingolani, A. M., \& Pérez Harguindeguy, N. (2014). Leaf litter mixtures and neighbour effects: Low-nitrogen and high-lignin species increase decomposition rate of high-nitrogen and low-lignin neighbours. Applied Soil Ecology, 82, 44-51.

Dignac, M.-F., Knicker, H., \& Kögel-Knabner, I. (2002). Effect of N content and soil texture on the decomposition of organic matter in forest soils as revealed by solid-state CPMAS NMR spectroscopy. Organic Geochemistry, 33, 1715-1726.

Edwards, C. A. (2007). The biology of soil: A community and ecosystem approach. biology of habitats. By Richard D Bardgett. Oxford and New York: Oxford University Press. 2006. The Quarterly Review of Biology, 82, 174-174.

Ekschmitt, K., Liu, M., Vetter, S., Fox, O., \& Wolters, V. (2005). Strategies used by soil biota to overcome soil organic matter stability why is dead organic matter left over in the soil? Geoderma, 128, 167-176.

Evans, S. E., \& Wallenstein, M. D. (2012). Soil microbial community response to drying and rewetting stress: does historical precipitation regime matter? Biogeochemistry, 109, 101-116.

Evans, S. E., \& Wallenstein, M. D. (2014). Climate change alters ecological strategies of soil bacteria. Ecology Letters, 17, 155-164.

Farnet, A.-M., Qasemian, L., Gil, G., \& Ferré, E. (2013). The importance of water availability in the reaction equilibrium of hydrolases in forest litters from a Mediterranean area: A study on lipases: The influence of water activity on enzymes in litters. European Journal of Soil Science, 64, 661-666.

Farnet, A. M., Qasemian, L., Guiral, D., \& Ferré, E. (2010). A modified method based on arsenomolybdate complex to quantify cellulase activities: Application to litters. Pedobiologia, 53, 159-160.

Farnet-Da Silva, A. M., Ferré, E., Dupuy, N., de la Boussinière, A., \& Rébufa, C. (2017). Infra-red spectroscopy reveals chemical interactions driving water availability for enzyme activities in litters of typical Mediterranean tree species. Soil Biology and Biochemistry, $114,72-81$.

Fierer, N., \& Schimel, J. P. (2003). A proposed mechanism for the pulse in carbon dioxide production commonly observed following the rapid rewetting of a dry soil. Soil Science Society of America Journal, 67, 798.

Fierer, N., Schimel, J. P., \& Holden, P. A. (2003). Influence of dryingrewetting frequency on soil bacterial community structure. Microbial Ecology, 45, 63-71.

Garcia-Fayos, P., \& Verdu, M. (1998). Soil seedbank, factors controlling germination and establishment of a Mediterranean shrub: Pistacia lentiscus L, Acta Oecologica 19, 10.

Garland, J. L., \& Mills, A. L. (1991). Classification and characterization of heterotrophic microbial communities on the basis of patterns of community-level sole-carbon-source utilization. Applied and Environmental Microbiology, 57, 9.

Giorgi, F., \& Lionello, P. (2008). Climate change projections for the Mediterranean region. Global and Planetary Change, 63, 90-104.

IUSS Working Group WRB. (2006). World reference base for soil resources 2006 (World Soil Resources Reports No. 103). Rome, Italy: FAO.

Jonsson, M. \& Wardle, D. A. 2008. Context dependency of litter-mixing effects on decomposition and nutrient release across a long-term chronosequence. Oikos, 117, 1674-1682. 
Knicker, H. (2011). Solid state CPMAS ${ }^{13} \mathrm{C}$ and ${ }^{15} \mathrm{~N}$ NMR spectroscopy in organic geochemistry and how spin dynamics can either aggravate or improve spectra interpretation. Organic Geochemistry, 42, 867-890.

Knicker, H., \& Lüdemann, H.-D. (1995). N-15 and C-13 CPMAS and solution NMR studies of N-15 enriched plant material during 600 days of microbial degradation. Organic Geochemistry, 23, 329-341.

Knorr, W., Holland, E. A., House, J. I., \& Prentice, I. C. (2005). Longterm sensitivity of soil carbon turnover to warming. Nature, 433 , 298-301.

Kosmas, C., Danalatos, N., \& Gerontidis, S. (2000). The effect of land parameters on vegetation performance and degree of erosion under Mediterranean conditions. Catena, 40, 3-17.

Li, Y., Chen, N., Harmon, M. E., Li, Y., Cao, X., Chappell, M. A., \& Mao, J. (2015). Plant species rather than climate greatly alters the temporal pattern of litter chemical composition during long-term decomposition. Scientific Reports, 5, 1-13. http://www.nature.com/ articles/srep15783

Loreau, M. (2010). Linking biodiversity and ecosystems: towards a unifying ecological theory. Philosophical Transactions of the Royal Society B: Biological Sciences, 365, 49-60.

Loreau, M., Naeem, S., Inchausti, P., Bengtsson, J., Grime, J. P., Hector, A., ... Wardle, D. A. (2001). Biodiversity and ecosystem functioning: Current knowledge and future challenges. Science, 294, 804-808.

Massiot, D., Fayon, F., Capron, M., King, I., Le Calvé, S., Alonso, B., ... Hoatson, G. (2002). Modelling one- and two-dimensional solidstate NMR spectra: Modelling 1D and 2D solid-state NMR spectra. Magnetic Resonance in Chemistry, 40, 70-76.

McLean, M. A., \& Huhta, V. (2000). Temporal and spatial fluctuations in moisture affect humus microfungal community structure in microcosms. Biology and Fertility of Soils, 32, 114-119.

Pachauri, R. K., Mayer, L., \& Intergovernmental Panel on Climate Change (Eds.). (2015). Climate change 2014: Synthesis report. Geneva, Switzerland: Intergovernmental Panel on Climate Change.

Pesaro, M., Nicollier, G., Zeyer, J., \& Widmer, F. (2004). Impact of soil drying-rewetting stress on microbial communities and activities and on degradation of two crop protection products. Applied and Environmental Microbiology, 70, 2577-2587.

Prescott, C. E. (2010). Litter decomposition: What controls it and how can we alter it to sequester more carbon in forest soils? Biogeochemistry, 101, 133-149.

Prescott, C. E., \& Grayston, S. J. (2013). Tree species influence on microbial communities in litter and soil: Current knowledge and research needs. Forest Ecology and Management, 309, 19-27.

Qasemian, L., Guiral, D., \& Farnet, A.-M. (2014). How do microlocal environmental variations affect microbial activities of a Pinus halepensis litter in a Mediterranean coastal area? Science of the Total Environment, 496, 198-205.

Quézel, P., \& Médail, F. (2003). Ecologie et biogéographie des forêts du bassin méditerranéen. Paris, France: Elsevier Masson.

Rimmer, D. L., \& Abbott, G. D. (2011). Phenolic compounds in $\mathrm{NaOH}$ extracts of UK soils and their contribution to antioxidant capacity. European Journal of Soil Science, 62, 285-294.

Saiya-Cork, K., Sinsabaugh, R., \& Zak, D. (2002). The effects of long term nitrogen deposition on extracellular enzyme activity in an Acer saccharum forest soil. Soil Biology and Biochemistry, 34, 1309-1315.

Santonja, M., Fernandez, C., Proffit, M., Gers, C., Gauquelin, T., Reiter, I. M., ... Baldy, V. (2017). Plant litter mixture partly mitigates the negative effects of extended drought on soil biota and litter decomposition in a Mediterranean oak forest. Journal of Ecology, 105, 801-815.

Sardans, J., \& Peñuelas, J. (2013). Plant-soil interactions in Mediterranean forest and shrublands: impacts of climatic change. Plant and Soil, 365, 1-33.

Schmitt, A., Glaser, B., Borken, W., \& Matzner, E. (2010). Organic matter quality of a forest soil subjected to repeated drying and different re-wetting intensities. European Journal of Soil Science, 61, 243-254.

Sheik, C. S., Beasley, W. H., Elshahed, M. S., Zhou, X., Luo, Y., \& Krumholz, L. R. (2011). Effect of warming and drought on grassland microbial communities. The ISME Journal, 5, 1692-1700.

Suseela, V., \& Tharayil, N. (2018). Decoupling the direct and indirect effects of climate on plant litter decomposition: Accounting for stress-induced modifications in plant chemistry. Global Change Biology, 24, 1428-1451.

Urbanová, M., Kopecký, J., Valášková, V., Ságová-Marečková, M., Elhottová, D., Kyselková, M., ... Baldrian, P. (2011). Development of bacterial community during spontaneous succession on spoil heaps after brown coal mining: Bacterial succession on postmining sites. FEMS Microbiology Ecology, 78, 59-69.

Vos, M., Wolf, A. B., Jennings, S. J., \& Kowalchuk, G. A. (2013). Micro-scale determinants of bacterial diversity in soil. FEMS Microbiology Reviews, 37, 936-954.

Wall, D. H., Bradford, M. A., St. John, M. G., Trofymow, J. A., Behan-Pelletier, V., Bignell, D. E., ... Zou, X. (2008). Global decomposition experiment shows soil animal impacts on decomposition are climate-dependent. Global Change Biology, 14, 26612677.

Wardle, D. A., \& Jonsson, M. (2014). Long-term resilience of aboveand belowground ecosystem components among contrasting ecosystems. Ecology, 95, 1836-1849.

Wu, D., Li, T., \& Wan, S. (2013). Time and litter species composition affect litter-mixing effects on decomposition rates. Plant and Soil, $371,355-366$.

Zimmer, M. (2002). Is decomposition of woodland leaf litter influenced by its species richness? Soil Biology and Biochemistry, 34, 277-284

\section{SUPPORTING INFORMATION}

Additional supporting information may be found online in the Supporting Information section at the end of this article. 